\title{
Abundance, prey, and activity period of dholes (Cuon alpinus) in Khao Yai National Park, Thailand
}

\author{
NORASET KHOEWSREE ${ }^{1}$, KHWANRUTAI CHARASPET ${ }^{1}$, RONGLARP SUKMASUANG ${ }^{1, \bullet}$, \\ NUCHARIN SONGSASEN ${ }^{2}$, MANANYA PLA-ARD ${ }^{1}$, JIDAPA THONGBANTUM ${ }^{1}$, WARAPORN KONGCHALOEM ${ }^{1}$, \\ KHANCHIT SRINOPAWAN ${ }^{3}$ \\ ${ }^{1}$ Forest Biology Department, Faculty of Forestry, Kasetsart University, Chatuchak District, Bangkok 10900, Thailand. `email: mronglarp@ gmail.com. \\ ${ }^{2}$ Smithsonian's National Zoo \& Conservation Biology Institute. 3001 Connecticut Ave., NW Washington, DC 20008, USA \\ ${ }^{3}$ Khao Yai National Park. Pakchong District, Nakorn Ratchasima Province 30450, Thailand
}

Manuscript received: 18 November 2019. Revision accepted: 29 December 2019

\begin{abstract}
Khoewsree N, Charaspet K, Sukmasuang R, Songsasen N, Pla-ard M, Thongbantum J, Kongchaloem W, Srinopawan K. 2020. Abundance, prey, and activity period of dholes (Cuon alpinus) in Khao Yai National Park, Thailand. Biodiversitas 21: 345-354. The abundance and occupancy of dholes in Khao Yai National Park are the highest among found carnivorous mammals. This demonstrates the importance of the home range of dholes. From the scat analysis, eight species of mammals that are prey can be identified. The dholes mainly consume ungulates when considering the most percentage of relative biomass consumed were ungulate species. For the number of prey animals consumed by dholes per year, a dhole consumes 25.94 prey animals per year which consist of 6.51 masked palm civets, 6.44 Asian palm civets, 4.55 muntjac, 3.97 lesser mouse-deer, 2.22 large Indian civets, 1.03 wild boars, 0.66 sambar, and 0.56 porcupines. From the daily activity pattern captured by the camera trap, dholes have an average activity period of 14:49 hours. Therefore, they are mostly diurnal. The results of the study confirm that Khao Yai National Park is an important habitat of dholes. To maintain the population of dholes in the area, the most important factor is maintaining the ungulate population in the area, especially muntjac, sambar, lesser mouse-deer, and wild boar by increasing and improving the quality of grassland, austerity of maintenance, garbage and dirt disposal from tourism activities in the area for ecological health, and public relations for dholes' conservation in the long-term.
\end{abstract}

Keywords: Camera trap, Scat analysis, Dong Pha Yen-Khao Yai Forest Complex

\section{INTRODUCTION}

Dholes (Cuon alpinus (Pallas, 1811) are medium-sized carnivorous mammals, which are a hyper carnivorous species (Van Valkenburgh 1991). They evolved suitably for hunting and consumed meat as their main source of food, amounting to more than 70\% (Johnsingh 1985). They have a close relationship in their pack including genetic relationships and have the ability to communicate from specific sounds, visual signs, contact, hearing, and smell. Therefore, they have high potential in hunting similar to tigers and leopards (Bailey et al. 2013). They are one of the few carnivorous mammals in the canid group that hunt as a group (Marshall-Pescini and Kaminski 2014). Normally, there are 5-12 members in a pack (Johnsingh 1982; Durbin et al. 2004) to increase the efficiency of hunting large prey such as banteng, gaur, and sambar. The number of pups per litter is from 2 to 8 (Cohen et al. 1978). Members in the pack participate in raising pups. From the hunting activity by many members of the pack, they need a big home range to support the population of prey which is mostly ungulates. For maintaining the dholes' population in the ecosystem properly, Kemler et al. (2012) stated that the home range of dholes' packs to maintain the population of dholes in the long term is five times bigger than that of tigers.
Therefore, overall, the population of dholes in every area is decreasing rapidly due to the change of habitat, hunting without controls, degeneration of habitat, and decreasing population of prey during the past decades (Wolf and Ripple 2016). Dholes are an endangered species (Kemler et al. 2015). At present, most dholes are in South Asia and Southeast Asia. The total population of adult dholes is 949-2,215 (Kemler et al. 2015), which is less than tigers and leopards in the wild and shows a decreasing trend (Kemler et al. 2015). Dholes are carnivorous and most closely related to the Ethiopian wolf and African wild dog (Gittleman 1989). Therefore, this is an evolutionary reason why they have only one estrous cycle in a year (monestrum). After females give birth, male dholes and members of the pack will find food and protect the territory (Asa and Valdespin 1998). For the study of prey species and prey selection of dholes which are mostly found in the South of India, the most important wildlife which is dholes' prey is the spotted deer (Axis axis) (Johnsingh 1992; Karanth and Sunquist 1995; Venkataraman et al. 1995; Andheria et al. 2007). The prey consumption of dholes also varies in terms of prey species. For example, the main species of dholes' prey in India are sambar, spotted deer, muntjac, and Burmese hares, including small rodents (Cohen et al. 1978; Johnsingh 1992; Karanth and Sunquist 1995; 2000; Andheria et al. 2007; Borah et al. 2009). Andheria et al. (2007) reported that dholes' foods in 
Bandipur Tiger Reserve are spotted deer78 \%, sambar13\%, wild boar4 \%, and gaur $1 \%$. In Nepal, the species of dholes' prey are sambar, muntjac, serows, and gorals (Wang and Macdonald 2009a; Thinley et al. 2011) while Aryal et al. (2015) found that the main prey is the blue sheep (Pseudois nayaur).

Grassman et al. (2005) reported that prey in Phu Khieo Wildlife Sanctuary, Chaiyaphum, Thailand, from 172 scat analyses, are mostly muntjac (42.6\%), sambar (31.5\%), wild boar $(23.6 \%)$ and hog deer $(14.2 \%)$. The main prey of dholes is ungulates, as shown in the studies in Laos (Kemler et al. 2012). Moreover, their consumption includes $13.9 \%$ of livestock, which makes agriculturists around the forests have a negative attitude toward dholes because of this disturbance (Wang and Macdonald 2006). Hayward et al. (2014) concluded that the prey of dholes from 24 studies in 16areas including the habitat and distribution are sambar, wild boar, spotted deer, gaur, and muntjac.

The size and weight of dholes' prey vary from 2.5-100 $\mathrm{kg}$ (Grassman et al. 2005; Andheria et al. 2007; Kawanishi and Sunquist 2008; Wang and Macdonald 2009a; Thinley et al. 2011). Karanth and Sunquist (1995) reported that dholes and leopards aim to hunt prey with a weight of 31 $175 \mathrm{~kg}$ while tigers aim to hunt prey with a weight of more than $176 \mathrm{~kg}$ when it depends on the area. Kumaraguru et al. (2011) reported that dholes hunt prey with an average weight of $36 \mathrm{~kg}$ in Anamalai Tiger Reserve, Southern India. Karanth and Sunquist (1995) reported that sambar, which was hunted by dholes, has an average weight of $70 \mathrm{~kg}$ which means dholes like to hunt young deer rather than adult deer. Sambar is the favorite or the second favorite prey of dholes (Cohen et al. 1978; Johnsingh 1992; Venkataraman et al. 1995; Grassman et al. 2005; Andheria et al. 2007; Borah et al. 2009; Thinley et al. 2011; Kamler et al. 2012). Maintaining the population of sambar and other related ungulates is the key to maintaining the population of dholes in the wild.

The differences in dholes' prey in each area may be related to the difference of habitat, the diversity of prey, and the size of the pack. Dholes in jungles usually have smaller packs than dholes in sparse forests or deciduous forests. Because the quantity of prey in jungles is lower than deciduous forests, dholes need to hunt small prey (Kawanishi and Sunquist 2008). However, Kawanishi and Sunquist (2008) stated that the prey that dholes prefer are small ungulates, especially lesser mouse-deer and muntjac. Hayward et al. (2014) reported the prey preference index of dholes in different areas. They found that the preferred prey of dholes, indicated by a positive index, are sambar, followed by Burmese hares. However, it was found that in the case of Burmese hare, the standard error of the electivity index is high, while the negative prey preference index was reported for wild boar, gaur, langurs, and Malayan porcupines. It is not found that dholes consume wild elephants and peacocks. The study to understand prey species and the abundance of dholes' prey, which are different depending on the area, is highly important to dhole conservation in different and changing environments in the present.

Moreover, the study of the abundance of prey and activity period of dholes related to human activities and prey from camera traps can improve the understanding of the efficient conservation of dholes. Khao Yai National Park was named as a World Natural Heritage site in 2005 due to the outstanding characteristics of the diversity of wildlife species (UNESCO 2019), including being an important habitat of dholes (Kanchanasaka et al. 2010; Jenks et al. 2011) and other wildlife in terms of conservation. Therefore, the study of the abundance of dholes' prey, prey preference, and activities according to the time appearing on camera traps in the areas which have never been studied before can improve the understanding of dhole conservation in the world natural heritage area in the future.

The objectives of this research were (i) To study the abundance of dholes and prey, including the prey preference of dholes in Khao Yai National Park. (ii) To study the activity period of dholes and prey in Khao Yai National Park from camera traps.

\section{MATERIALS AND METHODS}

\section{Khao Yai National Park}

Khao Yai National Park is located at $14^{\circ} 5^{\prime}-14^{\circ} 15^{\prime}$ North Latitude and $101^{\circ} 5^{\prime}-101^{\circ} 50^{\prime}$ East Longitude, and covers $2,168 \mathrm{~km}^{2}$ along with Phanom Dong Rak mountain range from the central to northeastern regions. It is the important origin of many rivers, such as the Nakhon Nayok River and Moon River. It was declared as a World Natural Heritage site in 2005 because of the diversity of wildlife. This is the habitat of more than 800 vertebrates which consist of 112 species of mammals, 392 species of birds, and more than 200 species of reptiles and amphibians. Among these, there are four endangered species, 19 vulnerable species, and one critically endangered species (UNESCO 2019). Most of the forest is a dry, evergreen forest, tropical rain forest, and hill evergreen forest. In addition, there is mixed deciduous forest and grassland from shifting farming in the past (UNESCO 2019). The study area is between Khao Yai Forest Fire Control Station and Khao Yai Training Center which covers $70 \mathrm{~km}^{2}$ approximately. The camera trap study was also covered form the center of the area to the northern boundary of the park where dhole was seen by the park rangers (Figure 1). The measurement of temperature and rainfall from the Mosingto measurement point in Khao Yai National Park shows that the 10-year average rainfall (2008-2017) is $1,897.07 \mathrm{~mm} /$ year. The maximum rainfall is from May to October. The maximum rainfall in September is 353.44 $\mathrm{mm}$. The average annual temperature of Khao Yai National Park is $21.28{ }^{\circ} \mathrm{C}$. The average highest temperature is in April at $30.33{ }^{\circ} \mathrm{C}$ and the lowest temperature is in January at $12.25^{\circ} \mathrm{C}$ (NPRD 2017). 


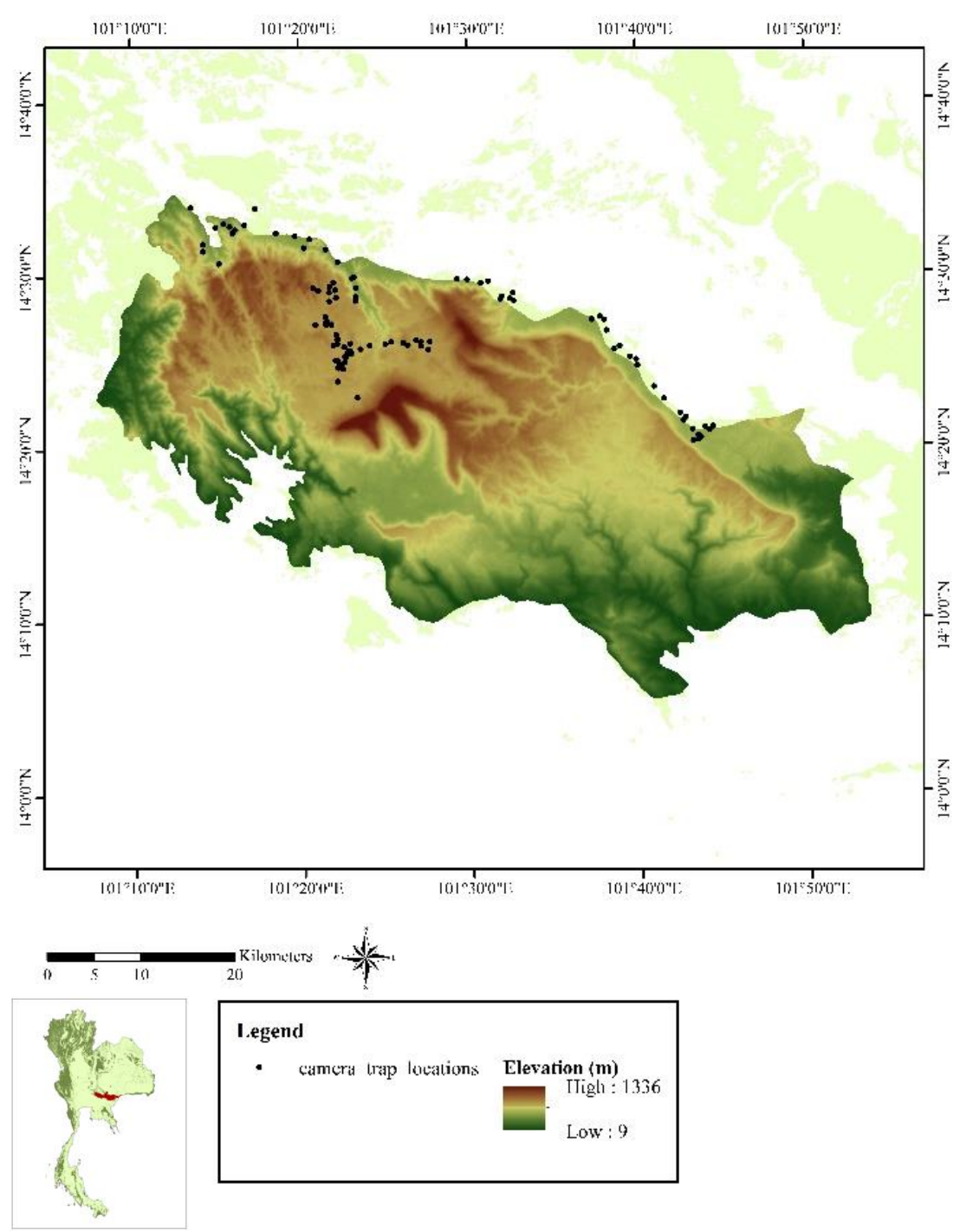

Figure 1. Map shows general characteristics of Khao Yai Nation Park, boundary and elevation, and also shows camera trap location during the study period between October 2017 and September 2018

\section{Field data procedure}

Study the abundance of dholes and prey by using automatic camera traps, twenty Bushnell Trophy Cam HD Essential E2 12MP Trail Camera sets were used during October 2017 and September 2018 and calculate the percentage of relative abundance (\%RAI) of dholes and main prey. One grid in the topographic map 1: 50,000 represents $1 \mathrm{~km}^{2}$. This study covers the entire area approximately $649.95 \mathrm{~km}^{2}$ when dragging a line connecting the camera position to the outer camera trap locations. A camera trap is installed in a grid (Gupta et al. 2009; Jenks et al. 2011; Siripattaranukul et al. 2015a, b) and monitors 15-20 grids per time. The location of the installed camera traps will be at least $500 \mathrm{~m}$ away from each other for the independence of the capture of each grid. This is to reduce the possibility of shooting the same animal by multiple cameras (Jenks et al. 2012). The selection of proper location for camera traps depends on the suitability of each area, such as animal route and traces (Prayoon et al. 2012;
Lynam et al. 2013; Wongchoo et al. 2013; Siripattaranukul et al. 2015a, b). Install camera traps $30-40 \mathrm{~cm}$ above the ground and about 3-4 $\mathrm{m}$ away from the target. Chutipong et al. (2014) defined shooting as when a sensor can detect motion by shooting three photos every 10 seconds for 24 hours (Network 2008) by setting camera traps for 30 days. After 30 days, the camera traps are relocated to new locations, and the newly installed locations of camera traps by GPS are recorded.

Photos are recorded on a computer and classified by Camera Trap Manager (Zaragozi et al. 2015) and imported to Microsoft Excel for further data analysis.

Collect scat of dholes along forest trails and animal routes, especially in the central of the study area. The total distance of the walking paths is about $100 \mathrm{~km}$ From February 2017 until September 2018, when scat is found, it is classified according to characteristics, and the size and footprints are measured in that area (Cohen et al. 1978; Johnsingh 1992; Karanth and Sunquist 1995; Selvan et al. 2013). Normally dhole packs hunt, feed, and often defecate 
together (Johnsingh 1982; Karanth and Sunquist 1995; Durbin et al. 2004; Thinley et al. 2011). Therefore, we sampled only 1 scat from each dropping to help ensure that the scats were from independent feeding events. Then, scat is collected in plastic bags. For each scat, the scat diameter, date, and GPS location were recorded.

\section{Laboratory Procedure}

The collected scats were washed in a laboratory and hair samples from each scat were identified for as to which species they belonged by examining the structures of the cuticle, medulla, and cross-section under a microscope and comparing these with a reference database of hair of the known species. Analyze the hair structure in the laboratory to determine the species of dholes' prey, which is a commonly used approach to identify the species of carnivorous wildlife's prey including dholes (Cohen et al. 1978; Johnsingh 1983; Andheria et al. 2007; Acharya et al. 2007; Arivazhagan et al. 2007; Edgaonkar 2008; Wang and MacDonald 2009a, b).

Rinse each scat of dholes and collect all the hairs in the scat. After that, eliminate oil by dishwashing liquid and detergent and remove dirt by ultrasonic machine. Then, pack the hairs in a paper envelop and dry at $60^{\circ} \mathrm{C}$ for 24 hours. Study the hairs by using acetone mixed with clear nail polish and put on a slide and wait until it is dry. Then, press the hairs on the nail polish until there is a mark on the nail polish. Remove the hairs and use a microscope to see and record the cuticle at the base, the middle, and the end of the hair.

Study the medulla by soaking hairs in xylene for about 24 hours to dissolve the colorant in the hair until the medulla is clearly visible when observed through a microscope. Record the pattern of the medulla in the middle and every different position. The identification of prey species can be done by comparing the recorded cuticle and medulla to reference slides of mammals by Phetdee (2000) and Slangsingha (2013).

\section{Data analysis}

Use photos from camera traps to identify species. Use common names and scientific names according to Lekagul and McNeely (1988) and only for the photos that can be identified clearly and show the date and time. If there is more than one photo showing the same species, then this will be counted once (Jenks et al. 2011) and the photos or situations which are independent are identified by criterion for independence of animal photographs according to O'Brien et al. (2003) as follows: (1) Continuous photos of different animals whether they are the same species are counted once; (2) Continuous photos of the same animal with the same species for which the duration is more than 30 mins are counted independently, and (3) Incoherent photos of the same animal with the same species are counted once (O'Brien et al. 2003).

Calculate the percentage of relative abundance (\%RAI) of each type of wildlife by using $\% \mathrm{RAI}=\mathrm{N}(100) / \mathrm{A}$ where $\mathrm{N}$ is the number of independent photos of each wildlife type multiplied by 100 and divided by A which equals the total number of trap days.
Frequency of occurrence (\%Frequency of Occurrence : $\% \mathrm{FO}$ ) of the prey species was calculated based on data combined and separated by season using the number of scat that the prey species presented multiplied by 100 and divided by the total number of all scat detections .

To determine selectivity for specific mammal species by dhole, we calculated Ivlev's electivity index (D) as modified by Jacobs (Jacobs 1974) as Electivity index (E):

$$
\mathrm{E}=\frac{(r-p)}{(r+p)-2 r p}
$$

Where $D$ is prey selectivity, $r$ is the proportion of a given prey species in the predator's diet (from percentage frequency of occurrence), and $p$ is the proportional availability, or abundance, of the prey species in the study area.

Ivlev's electivity index D was calculated, modified by Jacobs (1974), to assess which prey species were selected $(0<\mathrm{D} \leq 1)$ and which were avoided $(-1 \leq \mathrm{D}<0)$. We calculated D-values from data from both biomass consumed and individuals consumed, to determine if both methods showed similar trends. For each prey species, the D-value depends on which other species are included in the calculation. Therefore, we calculated D-values only for ungulate species for which abundances were determined during prey surveys. D-values of rare species are often biased e.g., a detection in 1 scat might lead to a D-value of +1 , whereas no detection would lead a D-value of- 1 . To determine biomass available for each ungulate species, we multiplied adult female body masses based on Lekagul and McNeely (1988) by the abundance estimates.

To determine numbers of individual prey consumed per dhole per year, we used the equation modified from Jedrzejewska and Jedrzejewski (1998):

$$
\text { Nprey }=\frac{(\text { DFIXBpreyXndays X100) }}{\text { BMprey }}
$$

Where, Nprey is the number of prey individuals consumed per dhole, DFI is the daily food intake of dholes, Bprey is the percentage biomass consumed by dholes for a given prey species, ndays is the number of days (i.e., 365 days in our analysis), and BMprey is the mean live body mass of prey. The daily food intake per dhole was assumed, conservatively, to be $1.36 \mathrm{~kg}$ based on the mean body mass $(16 \mathrm{~kg}$ ) given for dholes (Durbin et al. 2004), and that carnivores, in general, consume approximately $8.5 \%$ of their body mass per day (Mukherjee et al. 2004). The mean live body mass of prey species was the same as used to determine the percentage of biomass consumed.

The linear regression model $(y i=0.439+0.008 x i)$ developed for gray wolves (Canis lupus) by Weaver (1993) is used to calculate the biomass consumed of different prey species of dholes in the area. In the model, $x$ is the live body mass of prey, whereas $y$ is the mass of prey per collected scat (i).

Conclude the photo record time from camera traps by classifying times of 06:01-17:59 as day time and 18:0006:00 as nighttime (Azlan 2006). Use the data to create the 
graph of the hunting time of dholes and prey and compare the activity period of dholes with the times appearing on the photos by ORIANA version 4.02. Then, calculate the Mean Vector $(\mu)$ at a $95 \%$ Confidence Interval for $\mu$. Compare the appearance of dholes and prey within the area and between the other area by Hotelling's Test (Hotelling 1931). Then, consider the difference of appearance time from the photos at a significance level of $\mathrm{P}<0.05$.

Classify the activity period of dholes) Van Schaik and Griffiths 1996) by using the following concept. If the percentage of photos during the night time is more than $85 \%$, they are classified as strongly nocturnal; mostly nocturnal when the percentage is $61 \%-84 \%$, cathemeral when the percentage is $40 \%-60 \%$. If the percentage of photos during the day time is $61 \%-84 \%$, they are classified as mostly diurnal, and if it is more than $85 \%$, they are classified as strongly diurnal.

\section{RESULTS AND DISCUSSION}

\section{The abundance of dholes and prey}

For the results from the installation of camera traps in the survey area from October 2017 and September 2018, there are 72 total locations for the camera traps. The number of trap days is 1,795 . The resulting number of photos that are independent of each other is 2,052. They show 30 species of mammals, of which 19 species are carnivorous mammals and 11 of them are not carnivorous mammals. The carnivorous mammal which can be captured the most is the dhole, for which the abundance is $7.41 \%$, followed by large-spotted civet $(2.84 \%)$, golden jackal $(2.73 \%)$, large Indian civet (1.67\%), leopard cat (1.56\%), Asian palm civet (1.33\%), small Indian civet (1.05\%), crab-eating mongoose $(0.95 \%)$ and so on (Table 1$)$. Meanwhile, the 14 species of wildlife which are not carnivorous are the wild boar, which had the highest abundance at $22.06 \%$, followed by sambar (21.95\%), gaur $(17.21 \%)$, wild elephant $(8.24 \%)$, Malayan porcupine $(7.19 \%)$ and so on. The results of the study of the diversity of dholes and other carnivorous, non-carnivorous mammal species and dholes' prey, number of photos, and the number of camera trap locations of each species are shown in Table 1 .

\section{Identification of prey species from scat}

From 112 dholes scat can identify eight species of prey, which are mammals. They are sambar (Cervus unicolor), muntjac (Muntiacus muntjak), wild boar (Sus scrofa), masked palm civet (Paguma larvata), Asian palm civet (Paradoxurus hermaphroditus), large Indian civet (Viverra zibetha), lesser mouse-deer (Tragulus kanchil), and porcupine (Hystrix brachyura). Moreover, it was found that a group of scat contains only one prey species in $43.75 \%$ of cases, two prey species in $48.21 \%$ of cases, and three prey species in $8.04 \%$ of cases. For scat in which two and three prey species are found, besides ungulates, there are large Indian civets, Asian palm civets, masked palm civets, and porcupines. The result from the calculation of percentage of frequency of occurrence $(\% \mathrm{FO})$ of prey species which were found in scat shows that the muntjac has the highest frequency of occurrence at $41.96 \%$, followed by wild boar (24.29\%), sambar (16.07\%), masked palm civet (13.39\%), Asian palm civet $(11.60 \%)$, large Indian civet $(8.92 \%)$, lesser mouse-deer $(7.14 \%)$, and porcupine $(1.79 \%)$ as shown in Table 2.

\section{Electivity index}

Dholes in Khao Yai National Park mostly prefer to consume Malayan porcupines when the index is 0.23 followed by sambar (0.22), wild boar (0.12), muntjac ($0.06)$, large Indian civet (-0.38), Asian palm civets (-0.58), and lesser mouse-deer (-1.16) respectively. In this study, although dholes consume masked palm civets, the electivity index cannot be calculated because they are not found by camera traps. The results of this study are based on camera traps and calculated the abundance of prey because species can be clearly identified by photos, while exploring by footprints cannot be easily identified the species of wildlife, especially in the case of civets.

\section{Prey biomass consumed}

The prey of dholes in Khao Yai National Park from 112 scat analyzed is sambar, wild boar, and muntjac. When considering the percentage of relative biomass consumed, it is found that sambar has the highest value at $30.49 \%$, followed by wild boar (29.38\%) and muntjac (22.59\%). The smaller prey is masked palm civet $(5.38 \%)$, Asian palm civet $(4.66 \%)$, large Indian civet $(3.88 \%)$, lesser mouse-deer $(2.87 \%)$ and Malayan porcupine $(0.75 \%)$.

Most dholes' prey is ungulates $(85.33 \%)$ so ungulates are the main and most important prey for dholes in Khao Yai National Park. When considering the number of prey animals consumed by dholes per year, there are seven species consumed because masked palm civet in this area cannot be recorded. It is found that a dhole consumes 25.94 prey animals per year which consists of 6.51 masked palm civets, 6.44 Asian palm civets, 4.55 muntjac, 3.97 lesser mouse-deer, 2.22 large Indian civets, 1.03 wild boars, 0.66 sambar, and 0.56 Malayan porcupines as shown in Table 3.

\section{Activity period of dholes}

Dholes in Khao Yai National Park have the activity period during the day time rather than the night time. The number of prey species appearing during the day time is higher than during the night time based on camera traps. They consist of muntjac, wild boar, and lesser mouse-deer, which are the main prey of dholes. Sambar can be found during the night time rather than in the day time. Other prey which was found during the night time rather than the day time, included the Asian palm civet, large Indian civet, and Malayan porcupine, while humans were mostly found during the day time according to Figure 2. The appearance of dholes, which was used to indicate the daily activity of dholes, is based on independent photos from camera traps. It is found that dholes have an average $(\mu)$ activity period of 14:49 hours, with a $95 \%$ Confidence Interval for $\mu$ of 13:21 hours-16:17 hours $(n=119)$. 
Table 1. The abundance and species of wild mammal species, 19 carnivorous and 14 non-carnivorous species and dholes' prey in Khao Yai National Park, Thailand from the installation of camera traps between October 2017 and September 2018 in Khao Yai National Park. The total number of cameras is 72 and the number of day traps is 1,795 .

\begin{tabular}{|c|c|c|c|c|}
\hline Common name & Scientific & Picture & Location (\%) & \% RAI \\
\hline \multicolumn{5}{|l|}{ Carnivorous mammals } \\
\hline Dhole & Cuon alpinus & 133 & $20(27.78 \%)$ & 7.41 \\
\hline Large-spotted Civet & Viverra megaspila & 51 & $9(12.50 \%)$ & 2.84 \\
\hline Golden Jackal & Canis aureus & 49 & $12(16.67 \%)$ & 2.73 \\
\hline Large Indian Civet* & Viverra zibetha & 30 & $17(23.61 \%)$ & 1.67 \\
\hline Leopard Cat & Prionailurus bengalensis & 28 & $18(25.00 \%)$ & 1.56 \\
\hline Asian Palm Civet * & Paradoxurus hermaphroditus & 24 & $15(20.83 \%)$ & 1.33 \\
\hline Small Indian Civet & Viverricula indica & 19 & $9(12.50 \%)$ & 1.05 \\
\hline Crab-eating Mongoose & Herpestes urva & 17 & $10(13.89 \%)$ & 0.95 \\
\hline Small Asian Mongoose & Herpestes javanicus & 16 & $7(9.72 \%)$ & 0.89 \\
\hline Hog Badger & Arctonyx collaris & 12 & $6(8.33 \%)$ & 0.67 \\
\hline Asian Black Bear & Ursus thibetanus & 10 & $8(11.11 \%)$ & 0.56 \\
\hline Malayan Sun Bear & Helarctos malayanus & 10 & $7(9.72 \%)$ & 0.56 \\
\hline Yellow-throated Marten & Martes flavigula & 10 & $6(8.33 \%)$ & 0.56 \\
\hline Smooth-coated Otter & Lutrogale perspicillata & 3 & $1(1.39 \%)$ & 0.16 \\
\hline Clouded Leopard & Neofelis nebulosa & 2 & $2(2.78 \%)$ & 0.11 \\
\hline Marbled Cat & Pardofelis marmorata & 2 & $2(2.78 \%)$ & 0.11 \\
\hline Binturong & Arctictis binturong & 2 & $1(1.39 \%)$ & 0.11 \\
\hline Crab-eating Macaque & Macaca fascicularis & 2 & $1(1.39 \%)$ & 0.11 \\
\hline \multirow[t]{2}{*}{ Asian Golden Cat } & Catopuma temminckii & 1 & $1(1.39 \%)$ & 0.06 \\
\hline & Total & 421 & & 23.44 \\
\hline \multicolumn{5}{|l|}{ Non-carnivorous mammals } \\
\hline Wild Boar * & Sus scrofa & 396 & $35(48.61 \%)$ & 22.06 \\
\hline Sambar * & Cervus unicolor & 394 & $41(56.94 \%)$ & 21.95 \\
\hline Gaur & Bos gaurus & 309 & $27(37.50 \%)$ & 17.21 \\
\hline Asian Elephant & Elephas maximus & 148 & $35(48.61 \%)$ & 8.24 \\
\hline Malayan Porcupine * & Hystrix brachyura & 129 & $27(36.98 \%)$ & 7.19 \\
\hline Northern Red Muntjac * & Muntiacus muntjak & 127 & $42(58.33 \%)$ & 7.08 \\
\hline Northern Pig-tailed Macaque & Macaca leonina & 61 & $15(20.83 \%)$ & 3.40 \\
\hline Burmese Hare & Lepus peguensis & 30 & $9(12.50 \%)$ & 1.67 \\
\hline Lesser Mouse-deer * & Tragulus kanchil & 17 & $9(12.50 \%)$ & 0.94 \\
\hline Finlayson's Squirrel & Callosciurus finlaysonii & 10 & $3(4.17 \%)$ & 0.55 \\
\hline Gray-bellied Squirrel & Callosciurus caniceps & 6 & $5(6.94 \%)$ & 0.33 \\
\hline Asiatic Brush-tailed Porcupine & Atherurus macrourus & 2 & $1(1.39 \%)$ & 0.11 \\
\hline Crab-eating Macaque & Macaca fascicularis & 2 & $1(1.39 \%)$ & 0.11 \\
\hline \multirow[t]{2}{*}{ Southwest China Serow } & Capricornis milneedwardsii & 2 & $2(2.78 \%)$ & 0.11 \\
\hline & Total & 1,633 & & 90.95 \\
\hline
\end{tabular}

Note * prey species of dhole based on 112 dholes' scat

Table2 . Percentage frequency of occurrence (\%FO) of the prey species based on 112 dholes' scat in Khao Yai National Park, Thailand during October 2017 and September 2018.

\begin{tabular}{llcc}
\hline \multicolumn{1}{c}{ Common name } & \multicolumn{1}{c}{ Scientific name } & n=112 & \%FO \\
\cline { 2 - 3 } Muntjac & & 47 & 41.96 \\
Wild boar & Muntiacus muntjak & 25 & 22.32 \\
Sambar deer & Sus scrofa & 18 & 16.07 \\
Mask palm civet & Cervus unicolor & 15 & 13.39 \\
Asian palm civet & Paguma larvata & 13 & 11.60 \\
Large Indian civet & Paradoxurus hermaphrodites & 10 & 8.92 \\
Lesser mouse-deer & Viverra zibetha & 8 & 7.14 \\
Malayan porcupine & Tragulus kanchil & 2 & 1.79 \\
& Hystrix brachyura & & \\
\hline
\end{tabular}


Table 3. Prey species, average body weight of prey species, correction factor, percentage of relative biomass consumed, and a number of individuals of prey consumed by a dhole (Cuon alpinus) per year in Khao Yai National Park, Thailand based on scat samples ( $\mathrm{n}=$ 112).

\begin{tabular}{|c|c|c|c|c|c|}
\hline Common name & $\begin{array}{c}\text { Bodyweight (kg) } \\
\text { The average in } \\
{\text { parenthesis }{ }^{\prime} /}\end{array}$ & $\begin{array}{l}\text { Correction } \\
\text { factor) Yi }(2 /\end{array}$ & $\begin{array}{c}\text { \%frequency } \\
\text { of occurrence }{ }^{3} /\end{array}$ & $\begin{array}{l}\text { \%Relative biomass } \\
\text { consumed }{ }^{4 /}\end{array}$ & $\begin{array}{c}\text { No .of individuals of } \\
\text { prey } \\
\text { consumed/dhole/year } \underline{5} \text { / }\end{array}$ \\
\hline Sambar & $185-260(222.5)^{1)}$ & 2.22 & 16.07 & 30.49 & 0.66 \\
\hline Muntjac & $20-28(24.0)^{1)}$ & 0.63 & 41.96 & 22.59 & 4.55 \\
\hline Wild boar & $75-200(137.50)^{1)}$ & 1.54 & 22.32 & 29.38 & 1.03 \\
\hline Large Indian civet & $8-9(8.5)^{1)}$ & 0.51 & 8.92 & 3.88 & 2.22 \\
\hline Asian palm civet & $2-5(3.5)^{1)}$ & 0.47 & 11.6 & 4.66 & 6.44 \\
\hline Masked palm civet & $3-5(4.0)^{1)}$ & 0.47 & 13.39 & 5.38 & 6.51 \\
\hline Lesser mouse-deer & $2-5(3.5)^{1)}$ & 0.47 & 7.14 & 2.87 & 3.97 \\
\hline Malayan porcupine & $5-8(6.5)^{1)}$ & 0.49 & 1.79 & 0.75 & 0.56 \\
\hline Summary & & & & 100.00 & 25.94 \\
\hline
\end{tabular}

Notes: $\underline{1})=$ Lekagul and McNeely $(1988), \underline{2})=$ Weaver $(1993)(y i=0.439+0.008 x i), \underline{3})=$ This study, $\underline{4})=$ Ackerman et al. $(1984)$, $\underline{5})=$ Jedrzejewska and Jedrzejewski (1998): Nprey $=($ DFI $\times$ Bprey $\times$ ndays $) /$ BMprey $\times 100$

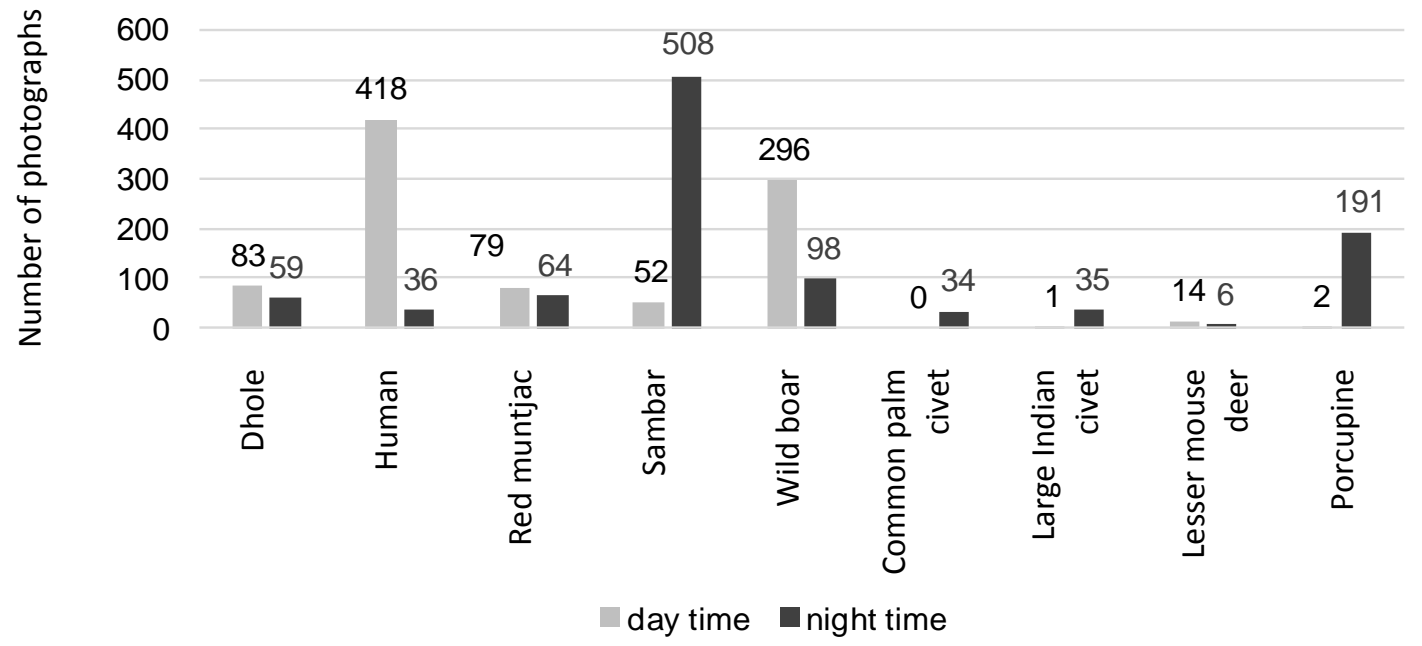

Figure 2. Activity patterns of dholes, tourists (human), and seven prey species consumed by dholes in Khao Yai National Park, Thailand, based on the time of independent camera trap photographs, also showing the number of photographs, in both day time and night time

Therefore, dholes in Khao Yai National Park can be classified as mostly diurnal (Schaik and Griffiths 1996). While the other seven prey species including muntjac have an average $(\mu)$ activity period of 09:07 hours with a 95\% Confidence Interval for $\mu$ of 07:01 hours-11:14 hours $(n=123)$. The sambar has the average $(\mu)$ activity period of 23:56 hours with a 95\% Confidence Interval for $\mu$ of $23: 23$ hours-00:28 hours $(\mathrm{n}=392)$; the wild boar has an average $(\mu)$ activity period of 13:00 hours with a 95\% Confidence Interval for $\mu$ of 12:30 hours-13:31 hours $(n=366)$; the lesser mouse-deer has the average $(\mu)$ activity period of 09:26 hours with a 95\% Confidence Interval for $\mu$ of 07:00 hours-11:52 hours $(n=17)$; the large Indian civet has the average $(\mu)$ activity period of 01:29 hours with a 95\% Confidence Interval for $\mu$ of 00:07 hours-02:51 hours $(n=27)$; the Asian palm civet has the average $(\mu)$ activity period of 00:22 hours with a 95\% Confidence Interval for $\mu$ of 22:59 hours-01:45 hours $(n=24)$; the Malayan porcupine has an average $(\mu)$ activity period of $22: 56$ hours with a 95\% Confidence Interval for $\mu$ of 22:17 hours-23:35 hours $(n=125)$, while the human has the average $(\mu)$ activity period of 12:52 hours with a 95\% Confidence Interval for $\mu$ of 12:34 hours-13:10 hours $(n=441)$. When considering the activity pattern of dholes from 119 photos, 83 of them are captured during the day time $(69.74 \%)$ while 36 of them are captured during the night time $(30.25 \%)$. From the study, the daily activity periods of dholes in Khao Yai National Park from photos of 7 prey species including the activity period of humans, are different significantly (Hotelling's Test=0.029, $\mathrm{P}=0.971$ ). 


\section{Discussion}

From the study, dholes have the highest abundance among carnivorous mammals in the area when the total number species is 19 . The occupancy of dhole in the area is also the highest compare with that of other carnivorous mammals. It is clear that dholes are the most outstanding form of carnivorous mammal in Khao Yai National Park which is the important habitat of dholes. When compared with other conservation areas such as Chalerm Rattanakosin National Park, Salak Phra Wildlife Sanctuary (Kanchanaburi Province), Huai Kha Khaeng Wildlife Sanctuary (Uthai Thani Province), and Khao Ang Rue Nai Wildlife Sanctuary (Chachoengsao Province), the carnivorous mammal with the highest abundance is the golden jackal (Siripattaranugul et al. 2015a, b; Ruengtik et al. 2019). For mammal wildlife species in the park which is not carnivorous, there are 14 species identified by camera trap found that the wild boar has the highest relative abundance index (\%RAI). The results of the study also find that Khao Yai National Park is the habitat of three endangered species, besides dholes, including wild elephant and large-spotted civet. Nine species are vulnerable, including the Asian black bear, Malayan sun bear, hog badger, clouded leopard, Binturong, smoothcoated otter, sambar, gaur, and northern pig-tailed macaque. Three species are near threatened including golden jackal, marbled cat, and serow. Seventeen species are least concerned. The total number of species of mammals is 33 .

The number of prey species found in scat is eight species. The muntjac has the highest frequency of occurrence, followed by wild boar, sambar, masked palm civet, Asian palm civet, large Indian civet, lesser mousedeer, and porcupine. The total percentage of occurrence of ungulates in scats is $89.46 \%$, which is close to the study by Slangsingha (2012) in Phu Khieo Wildlife Sanctuary, Chaiyaphum, which reported that \%88.30of prey in scat are ungulates. Meanwhile, Kamler et al. (2012) reported that prey species of dholes in the Nam Et-Phou Louey conservation area at the north of Laos are mostly ungulates $(88.20 \%)$ which consist of muntjac (55.3\%), sambar $(25.0 \%)$, and wild boar $(7.9 \%)$. Moreover, they consist of hog badger, serow, civet, porcupine, Asiatic striped squirrel, and Asian black bear.

This study also is consistent with Karanth and Sunquist (1995) who reported that prey species of dholes consist of 89-98\% ungulates. Moreover, Ramesh (2010) reported that dholes' prey in Mudumalai Tiger Reserve, Tamil Nadu, India, are mostly ungulate species up to $94.4 \%$, especially sambar and spotted deer from the analysis of 1,070 dhole scats. Moreover, they consist of monkeys, cattle, and others as reported by Venkatraman et al. (1995) who found that the main prey of dholes in Mudumalai, India, are spotted deer and sambar. In addition, Andheria et al. (2007) found that the main prey of dholes in Bandipur National Park is also spotted deer.

When considering the percentage of relative biomass consumed, confirms that ungulates, especially sambar, wild boar, muntjac, and lesser mouse-deer, are the main prey of dholes in Khao Yai National Park. From the study, dholes consume masked palm civet the most among the civet group. However, they are not found by camera traps either in this study or the study by camera traps of Jenks et al. (2012). Therefore, this issue should be further studied.

The study of prey species does not find the small rodents which have low body weight in dholes' scat such as grey-bellied squirrels and variable squirrels, while other studies found that the small rodents are also found in dholes' scat (e.g., Kamler et al. 2012; Slangsingha 2012; Charaspet 2015; Nurvianto et al. 2016). However, the proportion is low compared with the bigger prey. For example, it is found that dholes consumed the small rodents in Salak Phra Wildlife Sanctuary only six times from 176 scat (Charaspet 2015) although this study finds that the abundance of the variable squirrel is $0.55 \%$ and the greybellied squirrel is $0.33 \%$ from camera traps in the area. This may present the competition in hunting the small rodents between dholes and other carnivorous mammals which are found significantly in dholes' habitat that want to consume these small rodents, such as leopard cats $(\% \mathrm{RAI}=1.56)$, golden jackal (\%RAI=2.73) yellow-throated martens (\%RAI=0.56), marbled cats (\%RAI=0.11), clouded leopards (\%RAI=0.11), and Asian golden cats $(\% \mathrm{RAI}=0.06)$.

Therefore, dholes choose to consume the larger prey for the value of the energy of pack hunting according to the optimum forage theory. The prey preference of dholes does not depend on the size of the pack but the bigger the pack is, the more opportunity to consume the bigger prey for getting the optimum energy (Griffiths 1975; Hayward and Kerley 2005; Hayward et al. 2014). Moreover, it can improve safety in hunting as well (Sunquist and Sunquist 1997). However, the size of the dhole pack in the area may be limited by diversity and abundance of prey in the area. These indicate the abundance of prey, which are ungulates in the area, whether it is sufficient to maintain the population of dholes.

When considering the number of prey animals consumed by dholes per year, It is found that a dhole consumes 25.94 prey animals per year which consist of 6.51 masked palm civets, 6.44 Asian palm civets, 4.55 muntjac, 3.97 lesser mouse-deer, 2.22 large Indian civets, 1.03 wild boars, 0.66 sambar, and 056 . porcupines. The study by Kamler et al. (2012) in Nam Et-Phou Louey National Reserve in Laos stated that dholes consume 72.2 prey animals. Most prey are small rodents while large prey are 9.2 muntjacs, 2.3 sambars, one wild boar, 0.4 serows, 0.1 bears, 1.5 hog badgers, and 1.4 small porcupines. It is remarked that the consumption of small prey by dholes may be caused by the lack of the main prey in the area. Therefore, dholes choose to hunt small prey, while small rodents are not found in dholes' scat in Khao Yai National Park or they are consumed very little.

From the study, dholes have activities during the day time rather than night time at the park. The average activity period of dholes is 14:49hours, and mostly diurnal. The average activity period of dholes is not significant difference when compared with the period of dholes in Huai Kha Khaeng Wildlife Sanctuary located in the western part of the country $\left(11: 17\right.$ hours $\left.169.397^{\circ}, \mathrm{n}=22\right)$ 
(Charaspet et al. 2019) and Khao Ang Rue Nai Wildlife Sanctuary (10:41 hours $160.354^{\circ}, \mathrm{n}=732$ ) (Ruengtik et al. 2019) located in the eastern part of Thailand (Hotelling's Test $(\mathrm{F})=9.273, \mathrm{P}=0.226)$. That confirms the activity period of dholes in Thailand mostly occur during day time. This is consistent with Johnsingh (1982); Karanth and Sunquist (2000); Acharya (2007); Kawanishi and Sunquist (2008) and Majumder (2011) who found that dholes mostly hunt prey during the day time especially in the morning and afternoon, which is different from tigers and leopards that hunt during the night time until the morning. However, Ghaskadbi et al. (2016) reported that dholes at the TadobaAndhari Tiger Reserve, India, have the activity pattern as a crepuscular activity pattern as in the report by Nurvianto et al. (2016) which studied dholes on Java Island, Indonesia, which shows that dholes have the ability to adapt their hunting times. The most important factor in maintaining the dhole population is maintaining the ungulate population in the area, especially muntjac, sambar, lesser mouse-deer, and wild boar by increasing and improving grassland, austerity of maintenance, and garbage and dirt disposal from tourism activities in the area for ecological health, especially in controlling the pests that may occur in wildlife affecting both prey and carnivorous wildlife due to the human activity in the habitat. Moreover, during the study, it is found that dholes tend to go to the outside of the national park more often, and one dhole was killed by a car in February 2017. Therefore, the risk of the infection from dogs to dholes and other carnivorous wildlife is high. Moreover, the study encourages public awareness to reduce the risk of the distribution of domestic cat and domestic dog diseases, accidents, and the reduction of recreational activities in the area which has dholes for the benefit of conservation in the long term. The monitoring of ecology and ecological niches between dholes and other carnivorous wildlife is interesting and should be studied further.

\section{ACKNOWLEDGEMENTS}

This study is supported by Earthwatch, USA. The author would like to thank the volunteers of Earthwatch, the participants of the dholes research project in Thailand between 2019-2018 for their help in collecting scat and prey species by walking on the route and installing camera traps, the Center for Advanced Studies in Tropical Natural Resources, Kasetsart University, for supporting Ph.D. students, Dr. Thongtham Suksawang, Director of National Park Office, Dr. Saksit Simcharoen, Director of the Wildlife Research Group, and the Dean of the Faculty of Forestry, Kasetsart University, for supporting this study.

\section{REFERENCES}

Ackerman BB. 1984. Cougar food-habits in Southern Utah. J Wildl Manag 48 (1): 147-155.

Andheria AP, Karanth KU, Kumar NS. 2007. Diet and prey profiles of three sympatric large carnivores in Bandipur Tiger Reserve, India. J Zool 273: 169-175.
Aryal A, Panthi S, Barraclough RK, Bencini R, Adhikari B, Ji W, Raubenheimer D. 2015. Habitat selection and feeding ecology of dhole (Cuon alpinus) in the Himalayas. J Mammal 96(1): 47-53. DOI: 10.1093/jmamma/gyu001

Acharya B. 2007. The Ecology of the Dhole or Asiatic Wild Dog (Cuon alpinus) In Pench Tiger Reserve, Madhya Pradesh. [Dissertation]. Saurashtra University, Rajkot, Gujarat, India.

Arivazhagan C, Arumugam R, Thiyagesan K. .2007Food habits of leopard (Panthera pardus fusca), dhole (Cuon alpines) and striped hyena (Hyaena hyaena) in a tropical dry thorn forest of southern India. J Bombay Nat Hist Soc 104: 178-187.

Asa CS, Valdespino C. 1998. Canid reproductive biology: integration of proximate mechanisms and ultimate causes. Am Zool 38:251-259.

Azlan MJ, Sharma DSK. 2006. The diversity and activity patterns of wild felids in a secondary forest in Peninsular Malaysia. Oryx 40(1): 3641.

Bailey I, Myatt J, Wilson A. 2013. Group hunting within the carnivora: physiological, cognitive and environmental influences on strategy and cooperation. Behav Ecol Sociobiol 67: 1-17.

Borah J, Deka K, Dookia S, Gupta RP. 2009. Food habits of dholes (Cuon alpinus) in Satputra Tiger Reserve, Madya Pradesh, India. Mammalia 73: 85-88.

Charaspet K. .2015Prey Species and Habitat Use of Dhole (Cuon alpinus) in Salakpra Wildlife Sanctuary. [Thesis], Kasetsart University, Bangkok. [Thai]

Charaspet K, Sukmasuang R, Kheowsree N, Songsasen N, Simchareon S, Duengkae P. 2019. Some ecological aspects of dhole (Cuon alpinus) in the Huai Kha Khaeng Wildlife Sanctuary, Uthai Thani Province, Thailand. Folia Oecologica 46: 91-100.

Chutipong W, Lynam AJ, Steinmetz R, Savini T, Gale GA. .2014 Sampling mammalian carnivores in western Thailand: Issues of rarity and detectability. Raffles Bull Zool 535-521:62.

Cohen JA, Fox MW, Johnsingh AJT, Barnett BD. 1978. Food habits of the dhole in south India. J Wildl Manag 42: 933-936.

Durbin LS, Venkataraman A, Hedges S, Duckworth W. .2004Dhole (Cuon alpinus). In: Sillero-Zubiri C, Hoffmann M, Macdonald DW (eds). Canids: foxes, wolves, jackals and dog. Status survey and conservation action plan. IUCN/SSC Canid Specialist, Gland, Switzerland, and Cambridge, UK.

Edgaonkar E. 2008. Ecology of the Leopard Panthera pardus in Bori Wildlife Sanctuary and Satpura National Park, India. [Dissertation]. University of Florida, Miami, USA.

Gittleman J. 1989. Carnivore group living: comparative trends. In: Gittleman JL (ed.). Carnivore Behavior, Ecology, and Evolution, Vol I. Cornell University Press, Ithaca, USA

Grassman LI, Silvy NJ, Kreetiyutanont K. 2005. Spatial ecology and diet of the Dhole Cuon alpinus (Canidae, Carnivora) in north-central Thailand. Mammalia 69 (1): 11-19.

Gupta S, Mondal K, Sankar K, Qureshi Q. 2009. Estimation of striped hyena Hyaena hyaena population using camera traps in Sariska Tiger Reserve, Rajasthan, India. J Bombay Nat Hist Soc 106 (3): 284-288.

Ghaskadbi P, Habib B, Quresh Q. 2016. A whistle in the woods: an ethogram and activity budget for the dhole in central India. J Mammal 97(6):1745-1752.

Hayward MW, Lyngdoh S, Habib B. 2014. Diet and prey preferences of dhole (Cuon alpinus): dietary competition within Asia's apex predator guild. J Zool 294: 255-266.

Hayward MW, Kerley GIH. 2005. Prey preferences of the lion (Panthera leo). J Zool (Lond.) 267: 309-322.

Hotelling H. 1931. The generalization of Student's ratio. Ann Math Stat 2 (3): 360-378.

Jacobs J. 1974. Quantitative measurement of food selection-a modification of the forage ratio and Ivlev's electivity index. Oecologia 14: 413417.

Jedrzejewska B, Jedrzejewski W. 1998. Predation in Vertebrate Communities: the Białowiez a Primeval Forest as a Case Study. Springer-Verlag, Berlin, Germany.

Jenks KE, Chanteap P, Damrongchainarong K, Cutter P, Cutter P, Redford T, Lynam AJ, Howard J, Leimgruber P. 2011. Using relative abundance indices from camera-trapping to test wildlife conservation hypotheses-an example from Khao Yai National Park, Thailand. Trop Conserv Sci 4(2): 113-131.

Jenks KE, Songsasen N, Leimgruber P. 2012. Camera trap records of dholes in Khao Ang Rue Nai Wildlife Sanctuary. Canid News 1-5.

Johnsingh AJT. 1982. Reproduction and social behaviour of the dhole, Cuon alpinus (Canidae). J Zool 198: 443-463 
Johnsingh AJT. 1983. Large mammalian prey-predators in Bandipur. J Bombay Nat Hist Soc 80:1-5 7 .

Johnsingh AJT. 1985. Distribution and status of dhole Cuon alpinus Pallas, 1811 in South Asia. Mammalia 49: 203-208.

Johnsingh AJT. 1992. Prey selection in three sympatric carnivores in Bandipur. Mammalia 56:517-526.

Kamler JF, Johnson A, Vongkhamheng C, Bousa A. 2012. The diet, prey selection, and activity of dholes (Cuon alpinus) in northern Laos. J. Mammal. 93: 62-633.

Kamler JF, Songsasen N, Jenks K, Srivathsa A, Sheng L. Kunkel K. 2015. Cuon alpinus. The IUCN Red List of Threatened Species 2015 e.T5953A72477893. DOI: $\quad 10.2305 /$ IUCN.UK.2015 4.RLTS.T5953A72477893.en.

Kanchanasaka B, Tunhikorn S, Vinitpornsawan S. Prayoon U, Faengbubpha K. 2010. Status of Large Mammals in Thailand Wildlife Research Division, Department of National Parks Wildlife and Plant Conservation, Bangkok. [Thai]

Karanth KU, Sunquist ME. 1995. Prey selection by tiger, leopard and dhole in tropical forest. J. Anim. Ecol. 64: 439-450.

Karanth KU, Sunquist ME. 2000. Behavioural correlates of predation by tiger (Panthera tigris), leopard (Panthera pardus) and dhole (Cuon alpinus) in Nagarahole, India. J. Zool. 250: 255-265.

Kawanishi K, Sunquist ME. 2008. Food habits and activity patterns of the Asiatic golden cat (Catopuma temminckii) and dhole (Cuon alpinus) in a Primary rainforest of Peninsular Malaysia. Mammal Stud 33: 73 177.

Kumaraguru A, Saravanamuthu R, Brinda K, Asokan S. 2011. Prey preference of large carnivores in Anamalai Tiger Reserve, India. Eur. J. Wildl. Res. 57: 627-637.

Lekagul B, McNeely JA. 1988. Mammals of Thailand. Darnsutha Press, Bangkok.

Lynam AJ, Jenks KE, Tantipisanuh N, Chutipong W, Ngoprasert D, Gale GA, Steinmetz R, Sukmasuang R, Bhumpakphan N, Grassman LI. 2013. Terrestrial activity patterns of wild cats from camera-trapping. Raffles Bull. Zool. 61 (1): 407-415.

Majumder A. 2011. Prey Selection, Food Habits and Population Structure of Sympatric Carnivores Tiger (Panthera tigris tigris), Leopard (Panthera pardus) and Dhole (Cuon alpinus) in Pench Tiger Reserve, Madhya Pradesh, India. [Dissertation]. Saurashtra University, Gujarat, India.

Marshall-Pescini S, Kaminski J. 2014. The social dog: History and evolution. In: Kaminski J, Marshall-Pescini S (Eds.) The Social Dog: Behavior and cognition, Academic Press, London.

Mukherjee S, Goyal SP, Johnsingh AJT, Pitman MRPL. 2004. The importance of rodents in the diet of jungle cat (Felis chaus), caracal (Caracal caracal) and golden jackal (Canis aureus) in Sariska Tiger Reserve, Rajasthan, India. J. Zool. (Lond.) 262: 405-411.

NPRD (National Parks Research and Innovation Development Center) 2017. Attitudes and Opinions of Thai Tourists towards the Conservation of Crocodiles in Khao Yai National Park. National Parks Wildlife and Plant Conservation Department, Nakorn Ratchasima Province, Thailand. [Thai]

Network T. 2008. Terrestrial Vertebrate (Camera trap) Monitoring Protocol Implementation Manual. Arlington, VA., U.S.A.

Nurvianto S, Eprilurahman R, Imron MA, Herzog S. 2016. Feeding habit of pack living dhole (Cuon alpinus) in a dry deciduous forest of east Java, Indonesia. Taprobanica 8 (1): 10-20.

O'Brien TG, Kinnaird MF, Wibisono HT. 2003. Crouching tigers, hidden prey: Sumatran tiger and prey populations in a tropical forest landscape. Anim. Conserv. 6: 131-139. DOI $10.1017 / \mathrm{S} 1367943003003172$
Phetdee A. 2000. Food Habits of the Tiger (Pantera tigris Linnaeus) in Huai Kha Khaeng Wildlife Sanctuary by Fecal Analysis. [Thesis]. Kasetsart University, Bangkok. [Thai]

Ripple WJ, Estes JA, Beschta RL, Wilmers CC, Ritchie EG, Hebblewhite M, Berger J, Elmhagen B, Letnic M, Nelson MP, Schmitz OJ, Smith DW, Wallach AD, Wirsing AJ. 2014. Status and ecological effects of the world's largest carnivores. Science 343. https://www.ncbi.nlm.nih.gov/pubmed/24408439

Prayoon U, Bhumpakphan N, Sukmasuang R, Kanchanasaka B. 2012. Abundance and habitat suitability of dhole (Cuon alpinus) and their main prey in Thap Lan National Park. J Wildlife Thailand 19: 23-40. [Thai]

Ruengtik J, Sukmasuang R, Charaspet K, Pla-ard M, Panganta T, Duengkae P, Bhumpakphan N. 2019. Diversity and Abundance of Carnivorous Mammals in Khao Ang Rue Nai Wildlife Sanctuary, Chachoengsao Province. Thai J For. Imprinting. [Thai]

Selvan KM, Veeraswami GG, Hussain SA. 2013. Dietary preference of the Asiatic wild dog (Cuon alpinus). Mamm. Biol. 78: 486-489.

Siripattaranukul K, Bhumpakphan N, Sukmasuang R. 2015a. Diversity and abundance of carnivorous mammals in Salakphra Wildlife Sanctuary, Kanchanaburi Province. J Wildlife Thailand 22(1): 127 140. [Thai]

Siripattaranukul K, Paglia S, Sukmasuang R, Horradee S. 2015b. The study of diversity and abundance of wild animals in Chalerm Rattanakosin National Park by camera trapping. J Wildlife Thailand 22 (1): 91-100. [Thai]

Slangsingha N. 2012. Prey Species and Habitat Use of the Dhole (Cuon alpinus) in Phu Khieo Wildlife Sanctuary in Chaiyaphum Province. [Thesis]. Kasetsart University, Bankok. [Thai]

Thinley P, Kamler JF, Wang SW, Lham K, Stenkewiz U, Macdonald DW. 2011. Seasonal diet of dholes (Cuon alpinus) in northwestern Bhutan. Mamm. Biol. 76: 518-520.

Van Valkenburgh B. 1991. Iterative evolution of hypercarnivory in canids (Mammalia: Carnivora): Evolutionary interactions among sympatric predators. Paleobiology 17(4):340-362

Van Schaik CP, Griffiths M. 1996. Activity periods of Indonesian rain forest mammals. Biotropica 28: 105-112.

Venkataraman AB, Arumugam R, Sukumar R. 1995. The foraging ecology of dhole (Cuon alpinus) in Mudumalai Sanctuary, southern India. J. Zool. (Lond.) 237:543-561.

Wang SW, Macdonald DW. 2006. Livestock predation by carnivores in Jigme Singye Wangchuck National Park, Bhutan. Biol. Conserv. 129(4): 558-565.

Wang SW, Macdonald DW. 2009a. Feeding habits and niche partitioning in a predator guild composed of tigers, leopards and dholes in a temperate ecosystem in central Bhutan. J. Zool. 277: 275-283.

Wang SW, Macdonald DW. 2009b. The use of camera traps for estimating tiger and leopard populations in the high altitude mountains of Bhutan. Biol. Conserv. 142: 606-613.

Weaver JL. 1993. Refining the equation for interpreting prey occurrence in gray wolf scats. J. Wildl. Manag. 57: 534-538.

Wolf C, Ripple WJ. 2016. Prey depletion as a threat to the world's large carnivores. R. Soc. Open Sci 3: 160252. DOI: 10.1098/rsos.160252

Wongchoo K, Chimchome V, Simcharoen S, Duangchantrasiri S. 2013. Abundance and distribution of some viverrid species in Huai Kha Khaeng Wildlife Sanctuary. Thai J For 32: 1-9. [Thai]

UNESCO. 2019. Dong Phayayen-Khao Yai Forest Complex. https://whc.unesco.org/en/list/590

Zaragozí B, Belda A, Giménez P, Navarro JT, Bonet A. 2015. Advances in integration with GIS. Ecol. Inform. 30: 6-11. 